\title{
MENJAGA KONTINUITAS PADA SAAT PENGAMBILAN GAMBAR DALAM MEDIA FILM
}

\author{
Johanes Baptista Permadi \\ Jurusan Desain Komunikasi Visual, Fakultas Komunikasi dan Multimedia, \\ Bina Nusantara University, Jln. KH Syahdan No. 9, Palmerah, Jakarta Barat 11480 \\ johanesbp@yahoo.com
}

\begin{abstract}
Film media is a new media to communicate. However, the communication way in this movie is different from other media communication visual. Continuity is a crucial element in communicating through visual media, and sometimes continuity in a film is parted in a scene. The cause of losing continuity needs to be observed more, so there will be a method to anticipate losing continuity of a film in pre-production stage or in preparation stage before actual shooting. The data gained from students' assignments in 'Cinematography for Animation' subject, which close to problem formulation. After the data is gained and compared, there will be experiment using simulation towards application software $3 D$ to find alternative about continuity. The result covers the shooting way to keep continuity and a brave preparation in pre-production stage or before shooting.
\end{abstract}

Keywords: continuity, film, communication media, 3D, pre-production

\begin{abstract}
ABSTRAK
Media film merupakan media baru untuk berkomunikasi. Namun cara berkomunikasi dalam film sangatlah berbeda dibandingkan media komunikasi visual lainnya. Kontinuitas menjadi elemen penting dalam berkomunikasi melalui media visual, dan tidak jarang pula kontinuitas dalam sebuah film menjadi terputus pada suatu adegan. Penyebab hilangnya kontinuitas perlu diselidiki lebih lanjut, dengan demikian akan diperoleh suatu metode untuk mengantisipasi hilangnya kontinuitas dalam sebuah film dalam tahap pra-produksi atau dalam tahap persiapan sebelum pengambilan gambar yang sebenarnya dilakukan. Data diperoleh dari tugastugas mahasiswa dari mata kuliah "Cinematography for Animation", yang dekat dengan permasalahan yang akan dipecahkan. Setelah data terkumpul dan dibandingkan, eksperimen dengan menggunakan simulasi pada software aplikasi 3D dilakukan untuk mencari alternatif dalam menyiasati kontinuitas. Hasil yang diperoleh mencakup cara pengambilan gambar yang menjaga kontinuitas, dan persiapan yang matang pada tahap praproduksi atau sebelum pengambilan gambar yang sebenarnya dilakukan.
\end{abstract}

Kata kunci: kontinuitas, film, media komunikasi, 3D, pra-produksi 


\section{PENDAHULUAN}

Kemunculan media film dalam dunia desain komunikasi visual telah membuka cara baru dalam berkomunikasi. Keunggulan utama media film dalam berkomunikasi adalah gambar yang bergerak. Film dapat dengan jelas menggambarkan suatu gerakan, tidak seperti poster atau foto yang hanya memberikan kesan bergerak dalam suatu gambar. Dalam sebuah film, perubahan sudut pandang kamera selalu terjadi, terutama pada pergantian adegan, dimana sudut pandang kamera akan langsung berpindah ke tempat lain. Dalam dunia perfilman, hal ini dikenal dengan istilah cut. Apabila seorang sutradara kurang mengerti bagaimana mengimplementasikan pergantian cut dengan benar, maka adegan tersebut akan dapat menyebabkan kebingungan di pihak audiens, jika terjadi hal seperti ini, maka dapat dikatakan bahwa pergantian cut tersebut tidak memiliki kontinuitas yang kuat. Sebuah rangkaian cerita yang dikisahkan dalam bahasa film tanpa kontinuitas yang kuat akan menyebabkan cerita tersebut tidak dapat diterima atau dimengerti dengan baik oleh audiens.

Kontinuitas yang kuat dan konsisten merupakan salah satu faktor yang penting dalam penyampaian cerita. Berdasarkan pengamatan dari hasil karya visual para mahasiswa yang sedang mempelajari sinematografi, tidak konsisten dalam kontinuitas banyak terjadi, penyebab utamanya adalah perencanaan yang kurang baik dalam mengatur sudut pandang kamera.

\section{METODOLOGI PENELITIAN}

Permasalahan diidentifikasi setelah melihat hasil-hasil tugas mandiri mahasiswa dalam mata kuliah Cinematography For Animation. Dari 10 kelompok mahasiswa yang tugasnya diperiksa, 8 kelompok di antaranya memiliki perpindahan cut yang kurang berhubungan, dalam dunia sinematografi. Hal ini dikenal dengan istilah jumping.

Kesalahan kontinuitas yang dinamakan jumping paling umum terjadi adalah pada saat menentukan orientasi. Contoh dalam sebuah adegan, kamera berada di sebelah kanan si aktor yang akan melakukan adegan berjalan. Dalam sudut pandang kamera, aktor tersebut akan terlihat berjalan dari kiri ke kanan. Pada cut berikutnya, kamera berpindah ke sudut pandang lain, kali ini di sebelah kiri aktor tersebut. Maka dalam sudut pandang kamera, aktor tersebut akan terlihat berjalan dari kanan ke kiri. Pada cut pertama si aktor berjalan dari kiri ke kanan, namun pada cut selanjutnya si aktor berjalan dari kanan ke kiri. Hal ini akan menyebabkan kebingungan di mata audiens; kemanakah seharusnya si aktor berjalan? Apakah ke kiri ataukah ke kanan? Pada saat itulah orientasi menjadi tidak jelas dalam adegan tersebut. Dari kelompok yang membuat kesalahan ini, semua melaporkan bahwa tidak satupun adegan direncanakan terlebih dahulu dengan menggunakan storyboard.

Kasus lain yang terjadi pada kontinuitas selain dari ketidak-jelasan orientasi adalah perbedaan kondisi antara 2 cut yang berhubungan. Misalnya, dalam sebuah adegan, seorang aktor (A) berlari mendekati aktor lain (B) yang sedang diam berdiri di dekat tangga. Pada cut berikutnya, aktor A sampai kepada aktor B, dan aktor B sudah berdiri di atas anak tangga ke dua tanpa diperlihatkan bahwa aktor B sudah berjalan menaiki tangga. Kelompok yang melakukan kesalahan ini melaporkan bahwa lokasi pengambilan gambar tidak mendukung, sehingga untuk memuat kedua aktor tersebut dalam frame kamera dengan sudut pandang yang sesuai dengan storyboard, aktor B harus menaiki tangga terlebih dahulu.

Untuk mencari bagaimana cara untuk menjaga kontinuitas terutama pada perpindahan kamera, penulis menggunakan bantuan aplikasi software animasi 3D untuk membuat simulasi pergantian cut pada serangkaian adegan, dan mencari solusi apa saja yang dapat dilakukan untuk mencegah hilangnya kontinuitas dalam sebuah urutan adegan. 


\section{HASIL DAN PEMBAHASAN}

Dari hasil analisis laporan dan pengamatan terhadap tugas-tugas mahasiswa, dapat disimpulkan bahwa mayoritas kontinuitas terputus karena orientasi objek yang tidak konsisten. Hal ini disebabkan oleh perubahan sudut pandang kamera yang kurang tepat pada saat pengambilan gambar direncanakan, atau improvisasi penempatan sudut pandang kamera, dimana improvisasi tersebut tidak direncanakan dengan baik sebelum pengambilan gambar. Perubahan sudut pandang yang kurang tepat seringkali terjadi dalam kasus dimana orientasi objek utama berubah, namun perubahan orientasi objek ini bukan disebabkan karena objek tersebut benar-benar mengalami perubahan arah, tetapi disebabkan karena perubahan kamera yang melintasi line of action dari objek tersebut.

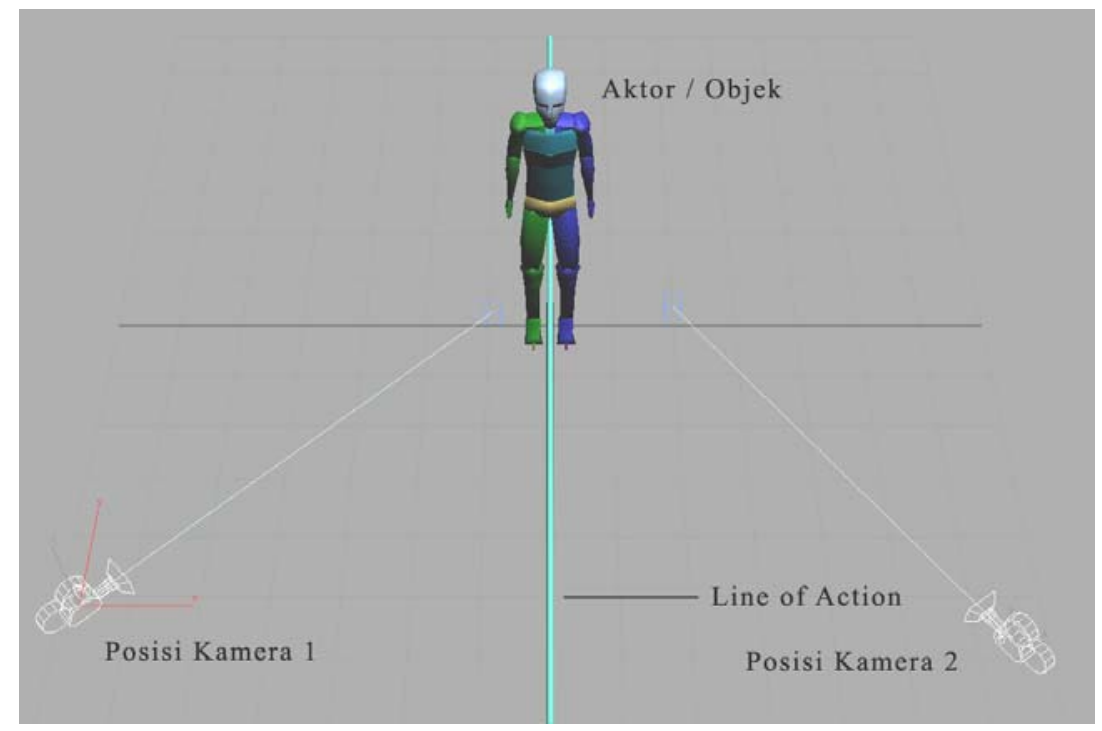

Gambar 1 Line of Action

Apabila pada cut 1 posisi kamera berada pada posisi kamera 1, dan pada cut 2 posisi kamera berada pada posisi kamera 2, di mana posisi kamera 2 telah melintasi line of action, maka ilusi perubahan orientasi sang aktor atau objek akan terjadi. Sesungguhnya aktor atau objek tersebut tidaklah berubah orientasi, namun perpindahan kamera yang melintasi line of action-lah yang akan menimbulkan ilusi bahwa objek tersebut mengalami perubahan orientasi. Perubahan orientasi tidak akan terjadi apabila audiens melihat pergerakan kamera melintasi line of action secara langsung. Yang menjadi masalah apabila perpindahan kamera dengan menggunakan cut, di mana audiens tidak menyaksikan arah pergerakan kamera maupun perubahan orientasi objek tersebut, maka yang terjadi adalah kebingungan pada pihak audiens.

Solusi pertama yang diperoleh untuk mencegah hilangnya kontinuitas yang disebabkan oleh terjadinya jumping adalah pada pergantian cut, posisi kamera tidak boleh melintasi line of action, posisi kamera harus berada pada sisi line of action yang sama dengan cut sebelumnya. Solusi kedua, apabila antara cut 1 dan 2 kamera perlu berpindah melintasi line of action, seorang sutradara harus memasukkan sebuah cut baru diantara cut 1 dan 2, dengan menempatkan kamera ditengah-tengah line of action untuk menetralkan orientasi objek tersebut sebelum memperlihatkan arah baru objek tersebut kepada audiens. Solusi ketiga adalah dengan menggunakan objek tersebut untuk merubah arah line of action tanpa menggerakan kamera. 


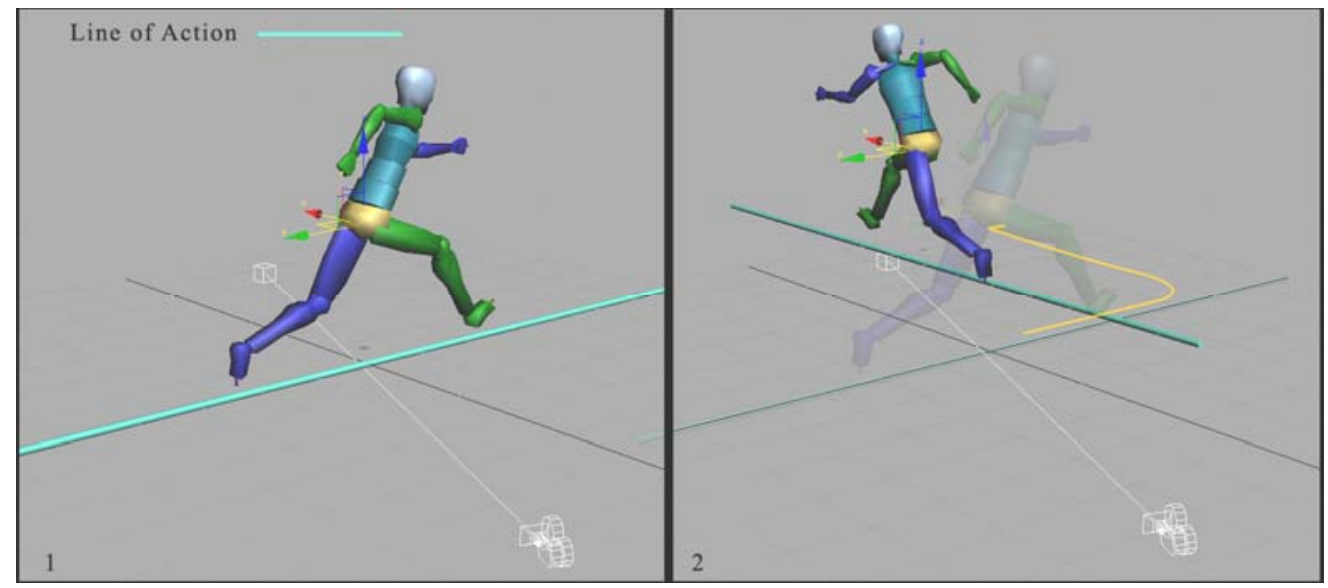

Gambar 2 Perubahan Line of Action

Jika aktor atau objek yang bersangkutan mengubah arah orientasi dan kamera tidak bergerak dalam satu cut, maka kamera akan melintasi line of action secara alami bersamaan dengan berubahnya orientasi si aktor atau objek tersebut. Solusi ketiga dapat digunakan apabila dalam sebuah adegan diperlukan pergerakan kamera yang melintasi line of action.

Sedangkan pada kasus kedua, kontinuitas menjadi terputus ketika keadaan dua cut yang saling bersambungan terlihat berbeda, mayoritas disebabkan oleh kondisi lokasi pengambilan gambar yang tidak memadai. Oleh karena itu, melakukan survei dan test ke lokasi pengambilan gambar dapat membantu untuk mengidentifikasi sudut-sudut pandang kamera yang tidak dapat dieksekusi karena berbagai macam hal, terutama keterbatasan lokasi, sehingga sudut pandang kamera alternatif dapat direncanakan terlebih dahulu sebelum pengambilan gambar yang sebenarnya dilakukan. Lokasi pengambilan gambar lain yang lebih memadai juga dapat dipertimbangkan apabila sudut pandang kamera tidak dapat diubah.

\section{SIMPULAN}

Kontinuitas merupakan masalah serius yang harus diperhatikan dalam pembuatan film. Kontinuitas dapat membuat perbedaan antara cerita yang tersampaikan dengan baik, atau membingungkan audien. Hilangnya kontinuitas mayoritas terjadi pada saat audiens merasa bingung karena perubahan orientasi yang disebabkan oleh perpindahan sudut pandang kamera ke lokasi yang kurang tepat, selain itu juga dapat disebabkan oleh kondisi dua cut berhubungan yang agak berbeda. Kurang terencananya storyboard, kelalaian, atau kurangnya pengetahuan sang sutradara adalah faktorfaktor utama yang menyebabkan hilangnya kontinuitas dalam film. Oleh karena itu, seorang director harus mengetahui apa saja faktor yang dapat mempertahankan kontinuitas dari awal hingga akhir film.

\section{DAFTAR PUSTAKA}

De Leeuw, B. (1997). Digital Cinematography. Sine Nomine.

Proferes, N. T. (2005). Film Directing Fundamentals. Focal Press.

Rabiger, M. (2003). Directing: Film Techniques and Aesthetics. Focal Press. 